\title{
Intestinal Microflora and Atopy Development in Infants during the First Nine Months
}

\author{
Jae-Seok Kim', Tae-Jung Sung², Hong Kyu Park', Ji Young Park', Hyoun Chan Cho', \\ II Tae Hwang', Hae-Ran Lee ${ }^{2}$
}

Departments of ${ }^{1}$ Laboratory Medicine, ${ }^{2}$ Pediatrics, Hallym University College of Medicine, Seoul, Korea

\begin{abstract}
Background: The intestinal microflora varies according to the factors such as age, diet and environment. It is debated whether the changes of microbiota after birth are associated with atopic disease. The purpose of this study was to investigate colonization rates of some intestinal microflora during the initial 9 months after birth, and their association with the development of atopy.

Methods: Stool specimens were collected at 1, 3, 7 days and at 1, 2, 4, 6, 9 months after birth, and Escherichia coli, Lactobacillus, Bifidobacterium, Staphylococcus aureus were cultured with selective media. Diagnosis for atopy was accomplished via clinical history of atopy, serum total $\mathrm{lgE}$, and skin prick test. Results: By 12 months of age, among 48 infants, 36 $(75.0 \%)$ were non-atopic while $12(25.0 \%)$ had developed atopy. Although not statistically significant, the intestinal microflora of infants with atopy vs. non-atopy was characterized by being less often colonized
\end{abstract}

with E. coli $(12.5 \%$ vs. $52.4 \% ; P=0.093)$ and $S$. aureus $(0 \%$ vs. $38.1 \% ; P=0.066)$ at three days after birth. Colonization rates of $E$. coli reached $50 \%$ after 3 days of birth in non-atopy group whereas this rate was not achieved until after 1 month in the atopy group.

Conclusion: The intestinal colonization rates of bacteria in this study were not statistically different between atopy and non-atopy groups. Rapid colonization of $E$. coli and $S$. aureus was observed within 1 week after birth in the non-atopy group. The exact association between atopy and the bacterial colonization and/or diversity in the early days after birth has yet to be determined. (Ann Clin Microbiol 2014; 17:73-79)

Key Words: Atopy, Colonization, Infant, Intestinal flora, Microbiota

\section{INTRODUCTION}

출생 후 신생아는 산도 주변이나 환경에 존재하는 다양한 세 균에 노출되며, 세균의 정착이 진행되고, 출생 직후부터 신생아 의 피부와 호흡기 등에서 세균이 분리된다. 그 중 일부 균종은 장내에 정착하여 사람과 세균의 공생관계가 지속되게 된다. 장 내 세균총은 신생아의 유전적 성향, 분만방법, 장내 정착 시기, 항생제 치료, 감염증, 위생, 나이 등 여러 요인에 의해 다른 양 상을 보이는 것으로 알려져 있다[1]. 장내의 세균 수는 10-100 조로 추정되며[1], 1,000-1,150개의 다양한 균종이 분리되나, 한 사람의 장내에는 160 균종이 우세균종으로 존재한다고 알려져 있다[2].

장은 음식이나 장내 세균 같은 다양한 항원의 자극이 발생하
는 곳으로 gut-associated lymphoid tissue (GALT)라는 인체에 서 가장 큰 면역기관이기도 하다. 또한, 이러한 장내의 세균의 분포나 차이가 아토피에 관여할 것으로 추정하고 있다[3]. 지금 까지 많은 연구에서 장내 세균총의 구성과 아토피의 연관성이 있음을 제시했지만, 아토피를 예방하거나 유발할 수 있는 특정 세균을 밝히지는 못하였다[3-5].

출생 직후부터 다양한 세균에 노출된 신생아에서는 면역 조 절 기능이 발달한다는 가설도 있으며, 아토피 군에서 상재균의 다양성이 낮다는 "biodiversity hypothesis"도 제시되고 있다. 또 한, 아토피는 출생 후 1 개월이내에 장내 세균총의 다양성이 낮 다고 하며[6], 피부 상재균의 종류가 많을수록 아토피가 적다는 연구도 있다[7].

분만법의 차이에 따라 산도 상재균 또는 피부 상재균에 대한 
노출이 달라서, 출생후 자연분만과 제왕절개술을 실시한 군에 서 출생 후 초기 장내 세균총의 차이가 발생할 수도 있다. 하지 만, 국내 영아에서는 출산 방법과 세균총의 변화를 관찰하는 연구는 거의 없으며, 출산방법과 소아 아토피의 연관성을 조사 한 연구에서는 일치된 결과를 보이지는 않았다[8,9].

이 연구에서는 영아에서 출생 후 9 개월간 장내 세균총 중 $E$. coli, Staphylococcus aureus, Bifidobacterium, Lactobacillus를 배양하여, 아토피 군과 비아토피 군에서의 정착률 차이를 알아 보고자 하였다. 또한, 전체 영아에서 출산방법에 따라 이들 세 균의 정착률 차이가 있는지를 조사하였다.

\section{MATERIALS AND METHODS}

\section{1. 대상}

2005년 7월에서 2006년 7월 사이에 서울시내 2개 종합병원 에서 출생한 정상 신생아를 대상으로 하였다. 연구 대상 신생 아는 모유 수유군 30 명, 분유 수유군을 90 명을 목표로 최소 4 개월간 식이를 유지하기로 하였으며, 중도에 혼합수유를 하거 나 3차에 걸친 아토피 검사를 시행하지 않은 경우, 분변 검체 수집이 어려운 경우는 제외하기로 하였다. 또한, 출생시 자연분 만 혹은 제왕절개술을 실시했는지 여부를 조사하였다. 신생아 의 직계 보호자가 연구에 대한 설명을 듣고 한 후 서면화된 동 의서를 작성하였다. 분변 검체는 생후 1 일, 3 일, 7 일에 채취하 였고, 1 개월, 2 개월, 4 개월, 6 개월, 9 개월에 자가에서 수집하였 으며 비닐 봉투에 밀봉하여 검사실로 운반하였다. 이 연구는 한림의대 강동성심병원의 임상시험 심사위원회 심의(IRB05-01) 를 통과하였다.

\section{2. 알레르기 검사}

아토피 가족력 및 알레르기 천식, 알레르기 비염, 아토피 피 부염 등의 병력은 생후 1 일, 6 개월, 12 개월에 3 차에 걸쳐 조사 하였다. 혈청 총 $\mathrm{IgE}$ 는 생후 4 개월, 9 개월에 시행하였고 CoatA-Count Total IgE immunoradiometric assay (DPC, Los Angelis, $\mathrm{USA}$ )로 측정하여 $13.0 \mathrm{IU} / \mathrm{mL}$ 이하를 정상으로 판정했다. 피부 반응검사는 생후 12 개월에 집먼지 진드기 2종, Dermatophagoides pteronyssinus (DP), Dermatophagoides farinae (DF)과 주요 식품 항원인 콩, 밀가루, 계란, 땅콩, 우유에 대해 시행하 였다. 각 항원에 대한 팽진이 $3 \mathrm{~mm}$ 이상이면 양성으로 판정하 고[10], 한 개 이상의 항원에 양성 반응을 보이는 경우를 아토 피라 정의하였다.

\section{3. 검체 처리}

분변의 무게를 측정한 후 $1 \mathrm{gram}$ 당 $10 \mathrm{~mL}$ 에 해당하는 생리 식염수를 가한 다음, 나무 막대로 균질화 시킨 후 가볍게 혼합 하였다. $10 \%$ 분변 부유액 $1 \mathrm{~mL}$ 와 생리식염수 $9 \mathrm{~mL}$ 를 혼합하
여 희석하여 첫번째 접종액을 만든 후 $100 \mu \mathrm{L}$ 를 생리식염수 $9.9 \mathrm{~mL}$ 에 혼합하여 계단 희석하였다. 최종적으로 1 검체당 4 단 계의 접종액을 만들어서 $100 \mu \mathrm{L}$ 씩 배지에 접종하였다. 이 연 구에서의 세균 검출 한계는 $1,000 \mathrm{CFU} / \mathrm{gram}$ 이었다.

\section{4. 세균 배양과 동정}

호기성 및 통성혐기성균 배양은 blood agar plate (BAP), $S$. aureus 검출은 mannitol-salt agar (MSA; Becton Dickinson, Sparks, MD, USA), E. coli 검출은 E. coli, coliform group chromogenic agar (chromogenic ECC; Oxoid, Hampshire, UK), Lactobacillus 검출에는 de Man-Rogosa-Sharpe agar (MRS; $\mathrm{BD})$, Bifidobacterium 검출에는 $5 \%$ horse blood 첨가 BL agar (BLA; BD)와 5\% horse blood BLA 1 L에 BS 용액(sodium propionate $6 \mathrm{~g}$, paromomycin sulfate $20 \mathrm{mg}$, neomycin $40 \mathrm{mg}$, lithium chloride $1.2 \mathrm{~g}$, 증류수 $20 \mathrm{~mL}$ ) $20 \mathrm{~mL}$ 를 혼합한 Bifidobacterium selective agar (BSA)를 사용하였다.

$\mathrm{BAP}$ 는 $\mathrm{CO}_{2}$ 배양기, $\mathrm{MSA}, \mathrm{ECC}$ 는 일반배양기를 사용하여 $37^{\circ} \mathrm{C}, 48$ 시간 배양하였고, MRS, BLA, BSA는 혐기성 상자에 서 $37^{\circ} \mathrm{C}, 72$ 시간 배양하였다.

전체 균주 수는 $\mathrm{BAP}$ 와 $\mathrm{BL}$ 에서 배양된 균집락의 수를 측정 하였고, MSA 배지에서 S. aureus가 의심되는 경우 그람염색과 coagulase, catalase, DNase, mannitol 검사로 동정하였다. ECC 에서 보라색을 보인 균집락이 자란 경우 E. coli로 동정하였다. MRS 배지에서 Lactobacillus spp.로 의심되는 경우 API $50 \mathrm{CH}$ kit (bioMérieux, Marcy-l'Etoile, France)를 이용하여 확인하였 다. $\mathrm{BL}$ 배지와 $\mathrm{BS}$ 배지에서 Bifidobacterium로 의심되는 경우 그람염색으로 확인 한 뒤 rapid ID 32A (bioMérieux)를 시행하 여 Bifidobacterium spp.를 확인하였다.

\section{5. 통계학적 분석}

본 연구에서 통계분석은 SPSS for Windows (version 15.0, SPSS Inc., Chicago, IL, USA)를 사용하였다. 아토피와 비아토 피 군에서 배양된 세균의 빈도는 chi-square test와 Fisher's exact test를 사용하여 분석하였으며 출생 후 1 일, 3 일, 7 일, 1 개월, 2 개월, 4 개월, 6 개월, 9 개월별로 두 군에서의 정착률 차이를 알 고자 하였다. $P$ 값이 0.05 미만인 경우를 통계적으로 유의한 것 으로 판정하였다.

\section{RESULTS}

연구 대상에 포함된 영아는 총 48 명이었으며 12 개월 후 아토 피로 확인된 영아가 12 명, 아토피가 없는 영아는 36 명이었다. 남녀 비율은 아토피 군에서 1.71:1 (남 7, 여 5), 비아토피군은 1.00:1 이었다(Table 1). 분만형태는 아토피 군이 정상분만 7명 $(58.3 \%)$, 제왕절개 5 명 $(41.7 \%)$ 이었으며, 비아토피 군의 정상분 
Table 1. Description of children included in the study

\begin{tabular}{lccl}
\hline \multicolumn{1}{c}{ Group } & $\begin{array}{c}\text { Atopy, No. } \\
(\%)(\mathrm{n}=12)\end{array}$ & $\begin{array}{c}\text { Healthy, No. } \\
(\%)(\mathrm{n}=36)\end{array}$ & $P$ value \\
\hline Boys & $7(58.3)$ & $18(50.0)$ & 0.6168 \\
Vaginal delivery & $7(58.3)$ & $16(44.4)$ & 0.4042 \\
Maternal atopy & $3(25.5)$ & $0(0)$ & 0.0127 \\
Paternal atopy & $3(25.5)$ & $2(5.6)$ & 0.0918 \\
Breast feeding & $2(16.7)$ & $8(22.2)$ & 1.0 \\
\hline
\end{tabular}

만은 16 명 $(44.4 \%)$, 제왕절개는 20 명 $(55.6 \%)$ 이었다. 가족력을 확인한 결과 아토피 군에서는 어머니가 아토피인 경우는 3 명 (25.5\%), 아버지가 아토피인 경우는 3 명 $(25.5 \%)$ 이었으며, 비아 토피 군에서는 어머니가 아토피인 경우는 없었으며, 아버지가 아토피인 경우는 2 명 $(5.6 \%)$ 이었다. 아토피 군 12 명 중 비염은 6 명(50.0\%), 피부반응 양성자는 7명(58.3\%)이었으며 비염과 피 부반응을 동시에 보인 경우는 1 명이었다. 피부반응검사 항원에

A
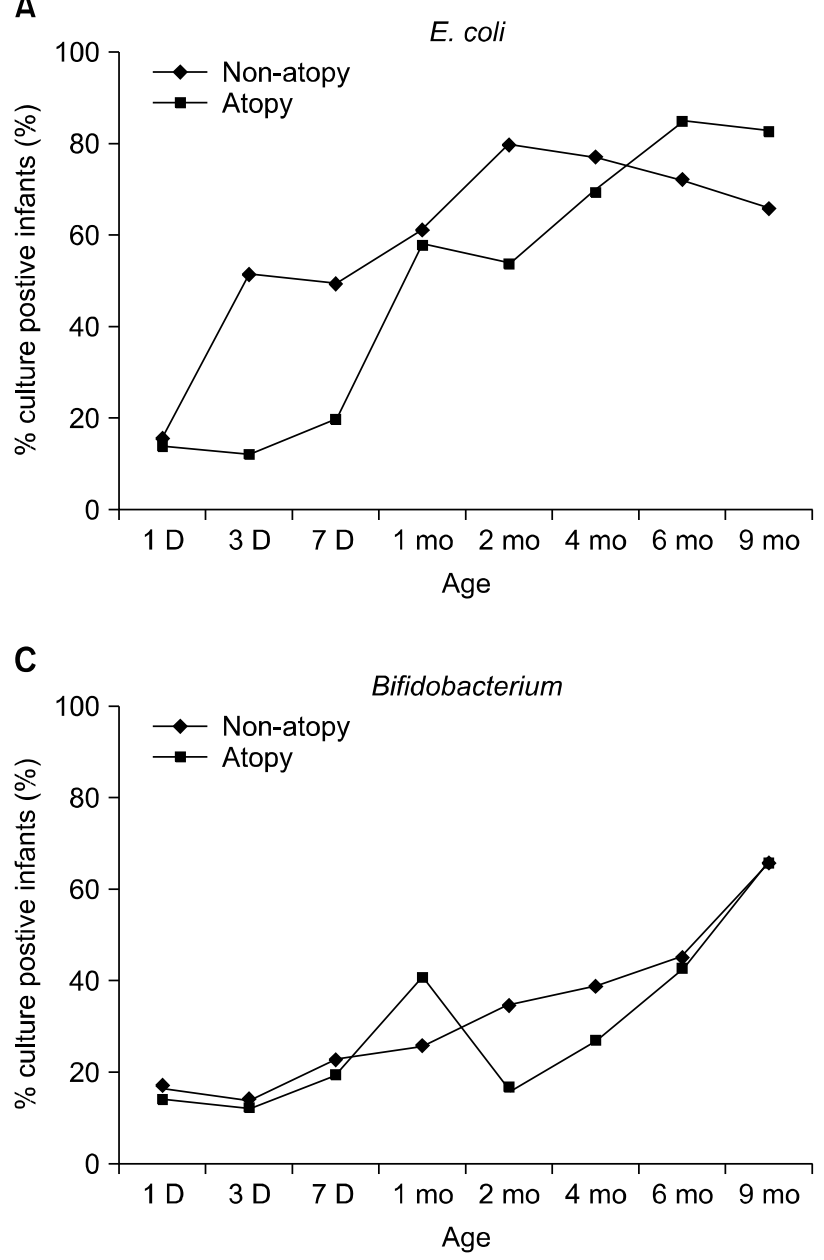

대해 1항목만 양성인 환자는 3명(콩 2, 밀가루 1), 2항목에서 양 성인 경우 1 명(밀가루/콩), 3 항목에서 양성인 경우 3 명(계란/땅 콩/콩, $\mathrm{DP} / \mathrm{PF} /$ 계란, $\mathrm{DP} /$ 밀가루/콩) 이었다.

9개월간 추적하면서 세균 배양을 위한 분변 검체를 얻을 수 있었던 영아의 수는 생후 1 일 검체 19 명(비아토피 12명, 아토 피 7명), 3일 29명(비아토피 21명, 아토피 8명), 7일 38명(비아 토피 28명, 아토피 10명), 1개월 41명(비아토피 29명, 아토피 12 명), 2개월 42명(비아토피 31명, 아토피 11명), 4개월 32명(비 아토피 22명, 아토피 10명), 6개월 29명(비아토피 22명, 아토피 7명), 9개월 12명(아토피 6명, 비아토피 6명)이었다. 8검체 모두 얻은 경우는 8 명, 7 검체는 4명, 6검체는 8 명, 5 검체는 8 명, 4검 체는 11 명, 3 검체는 7 명, 2검체는 2명이었다.

출생 후 E. coli의 정착률은 점점 증가하는 경향을 보여 1 개 월 이후 58.3-85.7\%의 분리율을 보였다(Fig. 1). 아토피 군의 정 착률은 1 일, 3 일, 7 일에 $14.3 \%, 12.5 \%, 20.0 \%$, 비아토피 군은 1 일, 3 일, 7 일에 $16.7 \%, 52.4 \%, 50.0 \%$ 를 보였으나 통계적으로

B

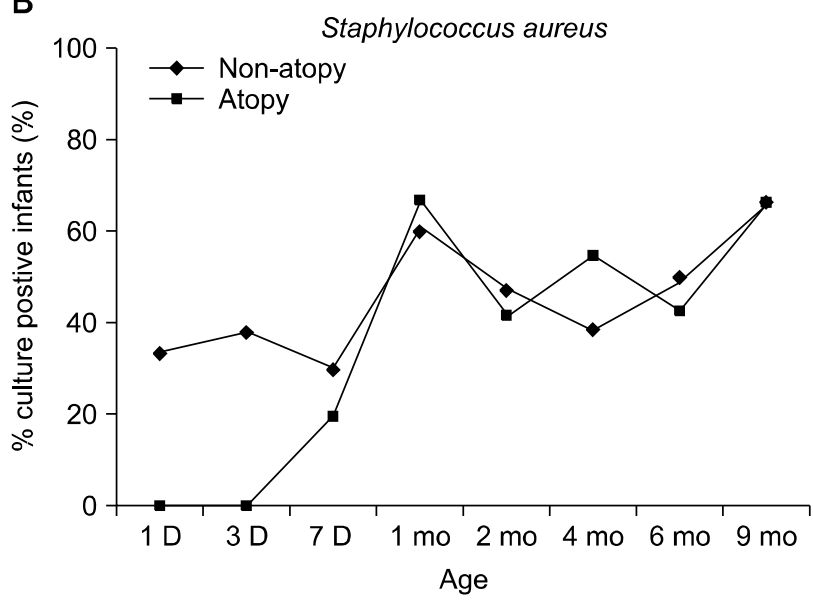

D

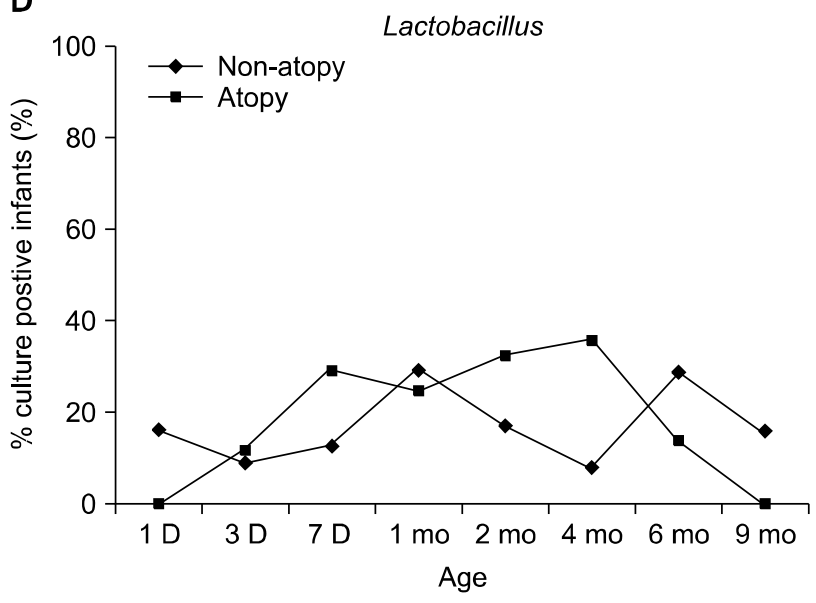

Fig. 1. Intestinal colonization rate in infants with allergic or nonallergic patients. At 3 days of age, the colonization rates of (A) Escherichia coli and (B) Staphylococcus aureus in nonallergic group (52.4\% and 38.1\%) was higher than those of allergic group (12.5\% and $0 \%)$, without statistical significance $(P=0.093$ and $P=0.066$. No significant differences were observed in (C) Bifidobacterium and (D) Lactobacillus colonization. 
Table 2. Intestinal colonization rate in all the infants after birth

\begin{tabular}{|c|c|c|c|c|c|c|c|c|}
\hline \multirow{2}{*}{ Bacteria } & \multicolumn{8}{|c|}{ Intestinal colonization rates } \\
\hline & $1 D(n=19)$ & $3 \mathrm{D}(\mathrm{n}=29)$ & $7 \mathrm{D}(\mathrm{n}=38)$ & 1 Mo $(n=41)$ & 2 Mo $(n=42)$ & 4 Mo $(n=32)$ & 6 Mo $(\mathrm{n}=29)$ & 9 Mo $(\mathrm{n}=12)$ \\
\hline E. coli & $15.8 \%$ & $41.4 \%$ & $42.1 \%$ & $61.0 \%$ & $73.8 \%$ & $75.0 \%$ & $75.9 \%$ & $75.0 \%$ \\
\hline S. aureus & $21.1 \%$ & $27.6 \%$ & $28.9 \%$ & $61.0 \%$ & $42.9 \%$ & $46.9 \%$ & $55.2 \%$ & $66.7 \%$ \\
\hline Bifidobacterium & $15.8 \%$ & $13.8 \%$ & $23.7 \%$ & $29.3 \%$ & $31.0 \%$ & $34.4 \%$ & $48.3 \%$ & $66.7 \%$ \\
\hline Lactobacillus & $10.5 \%$ & $10.3 \%$ & $18.4 \%$ & $29.3 \%$ & $23.8 \%$ & $21.9 \%$ & $27.6 \%$ & $8.3 \%$ \\
\hline
\end{tabular}

는 유의한 차이가 없었다 $(P=1.000, P=0.093, P=0.143)$.

S. aureus는 아토피군에서 1일, 3 일째는 검출되지 않았으나 비아토피군에서는 $33.3 \%, 38.1 \%$ 가 검출되었다. 하지만, 1 일과 3 일째 정착률의 통계적 차이는 없었다 $(P=0.245, P=0.066)$. 1 개 월 이후에도 두 군의 정착률의 차이는 없었고, 39.1-66.7\% 범위 를 보였다(Fig. 1).

Bifidobacterium 의 출생후 분리율은 출생 1 일째 아토피 군 $14.3 \%$, 비아토피 군 $16.7 \%$ 로 부터 9 개월째 아토피 군 $66.7 \%$, 비아토피 군 $66.7 \%$ 을 보여 증가하는 추세였으나, 연구기간 중 아토피군과 비아토피군의 차이는 없었다.

Lactobacillus 의 분리율은 아토피 군에서 $0-40.0 \%$, 비아토피 군에서 9.5-31.8\%의 범위를 보였으며, MRS 배지에서 다른 세 균과 같이 분리되는 경우가 많아서 다른 균종의 분리율 보다는 낮았다.

아토피군과 비아토피군을 포함한 전체 영아의 출생후 정착 률은 다음과 같다(Table 2).

장내에 상재균으로 알려진 E. coli와 Bifidobacterium은 자연 분만과 제왕절개 분만법의 차이에 따라 다를 것으로 추정되었 지만, 이번 연구 결과 큰 차이는 관찰되지 않았다(Fig. 2).

모유 수유와 분유 수유에 따른 비교는 계획과 달리 대상군에
서 이탈하는 경우가 많았기 때문에 대상군 수가 적었고 따라서 의미있는 결과를 얻기 어려웠다. 간략히 결과를 제시하면, 모유 수유군 10 명 중 아토피 발생은 2 명 $(20 \%)$ 였으며 분유 수유군 38 명 중 아토피 발생은 10 명(26.3\%)이었으며 $(P=1.000)$, 가족력 에서 어머니의 아토피 병력이 있는 6명을 제외한 경우, 모유 수 유군 7명 중 아토피 발생은 1 명(14.3\%)이고, 분유 수유군 35명 중 아토피 발생은 8 명 $(18.2 \%)$ 으로 차이가 없었다 $(P=1.000)$.

\section{DISCUSSION}

장내 세균총은 출생 직후에는 산도나 주위환경에 유래한 세 균이 자리잡은 뒤에 다양한 균종이 정착되는 것으로 알려져 있 다. 장내 세균총은 장내에서 대사 과정에 관여하며 다른 병원 균으로부터 장을 보호하고 면역계의 발달과 균형에 영향을 미 친다고 알려져 있으므로[11], 장내 세균총과 아토피와의 연관 성에 대한 연구가 많이 시행되었다. 출생 초기 E. coli나 S. aureus, C. difficile의 정착과 아토피 발생, Bifidobacterium이 정착 된 군에서 아토피 예방 효과를 관찰한 연구도 있으며, 균종별 로 세분화하여 영아 아토피 군에서 특정 Bifidobacterium 균종 이 검출되지 않았다는 보고[1,4,11]도 있을 정도로 다양한 연구
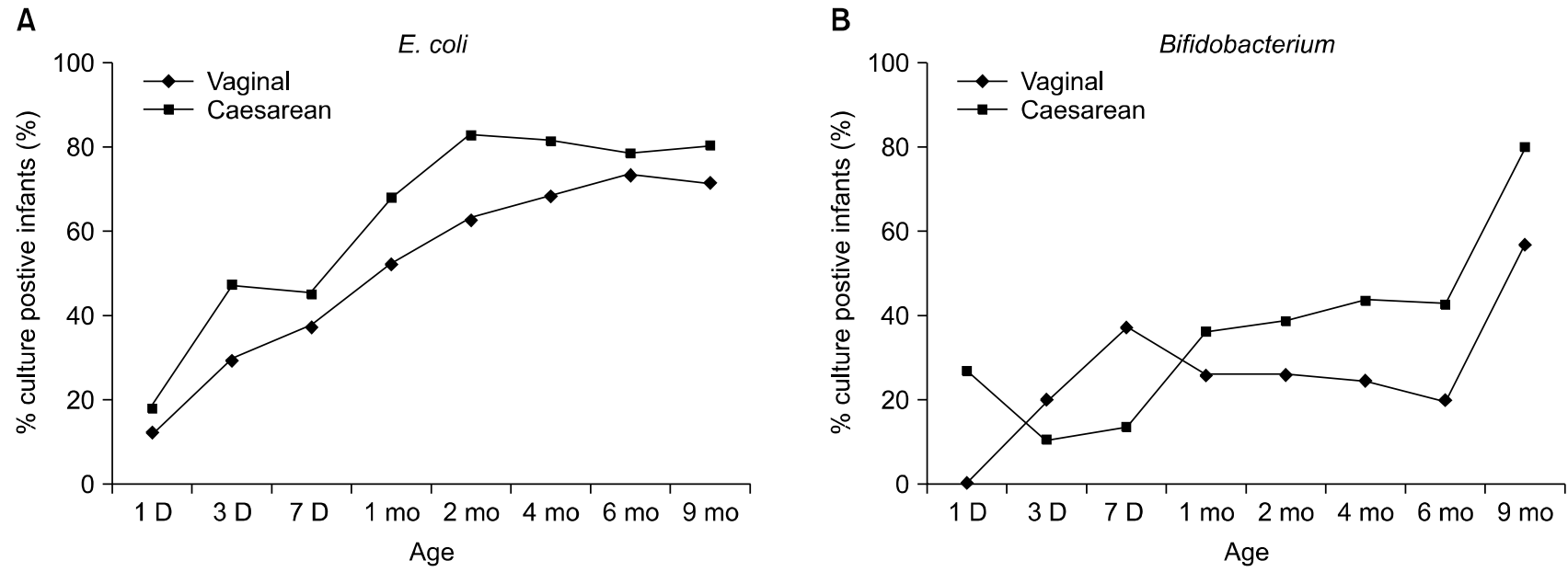

Fig. 2. Intestinal colonization rate of (A) E. coli and (B) Bifidobacterium in infants vaginally delivered and by caesarean section. Half of the infants had E. coli after 1 months of age, while half had Bifidobacterium at 9 months of life. There was no difference in colonization rate between these two groups during 9 months. 
결과가 제시되고 있다.

장내 세균총은 다양한 세균으로 이루어져 있으나, 이 연구에 서는 E. coli, S. aureus, Bifidobacterium, Lactobacillus 등의 장 내 정착을 알아보고자 하였다. E. coli는 주요 장내세균 중의 하 나로서, 자연분만 시 산도 주위에서 유래한 세균이 신생아의 장에 정착하는 것으로 알려져 있다. S. aureus는 그람양성구균 으로서 아토피 발생과 연관되어 있으며 아토피 증세를 악화시 키기도 한다[4,12]. Bifidobacterium 과 Lactobacillus는 일반적으 로 아토피 군에서 장내 정착이 지연된다고 알려져 있다[13].

이번 연구에서 대상군이 적어서 모유, 분유 수유군에서의 장 내 세균 정착은 차이는 관찰하기 어려웠다. 하지만, 기존의 보 고에서 모유수유는 아토피피부염과 소아 초기 천명을 예방하 며, 아토피를 방어하는 효과가 있을 것으로 보이며, 아토피의 위험요소나 어머니의 천식 병력에 관계없이 영아에서는 4-6개 월간 완전 모유 수유를 권장하고 있다[14].

장내 세균총은 모유 수유 등의 식이, 출산법, 환경노출, 유전 적 차이, 검사법 등의 차이로 인해 다양한 결과를 보인다. 따라 서, 아토피의 원인으로 특정 세균을 지목하기는 어려우며, 일부 균종의 경우 의미 없다는 보고도 있다[3].

이번 연구에서 출생 후 1 일, 3 일, 7 일, 1 개월, 2 개월, 4 개월, 6 개월, 9 개월 시기에 아토피 군과 비아토피 군의 장내 세균 정 착을 분석한 결과, 균 정착은 출생 후 시기에 따라 변화가 있었 으나 각 균종의 장내 정착과 아토피 발생의 통계적인 유의성은 관찰되지 않았다. 출생 초기에 가장 큰 차이를 보인 것은 $E$. coli와 S. aureus였다. 출생후 3일째 E. coli는 아토피 군의 $12.5 \%$ (8명 중 1명), 비아토피 군의 $52.4 \%$ (21명 중 11명)에서 분리되 었으며, S. aureus는 아토피 군의 $0 \%$ (8명 중 0 명), 비아토피 군 의 $38.1 \%$ (21명 중 8 명)에서 분리되어 E. coli와 S. aureus는 비 아토피 군에서 정착률이 높았지만 통계적인 유의성은 없었다. 하지만, 각 군의 수가 적은 편이므로 통계적인 의의를 확인하 기 위해서는 추가적인 연구가 필요할 것으로 생각한다.

전체 영아의 3 분의 1 은 자연 분만시 산모의 $E$. coli에 의해 장관 집락이 형성되지만, 1970년대에는 선진국에서도 출생 후 수일 이내에 의료인을 통해 E. coli가 정착되는 경우가 상당수 있었으며, $70 \%$ 의 영아에서 생후 1 주일 이내에 E. coli가 분리 되었다고 한다. 그러나, 최근에는 병원과 가정의 위생환경 향상 으로 E. coli의 장내 정착 시기가 늦어지고 있으며, 1990년대 말 스웨덴 영아에서 E. coli는 출생 후 3 일째 $42 \%, 2$ 주일째 $50 \%$, 2 개월째 $61 \%$ 에서 분리되어, 영아에서 E. coli가 정착되는 시기 가 최근에는 지연되고 있다[15]. 이번 연구에서는 전체 영아의 E. coli 정착률은 출생후 3 일째 $41.4 \%$ (29명 중 12 명), 2 개월에 $73.8 \%$ (42명 중 31명)으로 1990년대 말 스웨덴의 보고와 큰 차 이가 없었으므로, 우리나라의 출산 환경이 크게 다르지 않을 것으로 추정된다. 하지만, 이때의 스웨덴 보고에서는 출생 3 일 째 알러지 군과 비알러지 군에서 E. coli의 정착률은 동일하게
$42 \%$ 를 보여 두 군간의 차이는 없었다[15].

이번 연구에서 비아토피 군에서 출생후 1 주일 이내에 E. coli 와 S. aureus가 조기 정착하는 경향을 보였으나 통계적인 유의 성이 관찰되지 않았으므로 세균 정착의 지연이 아토피와 연관 되어 있다고 말하기는 어렵다. 장관내 세균총은 다양한 세균으 로 구성되어 있으므로 이 두 균종의 정착과 아토피 발생을 연 관시키기는 어렵지만, 아토피 발생의 소인이 있는 유아에서는 흔히 분리되는 세균의 정착이 늦을 가능성에 대해서는 추가적 인 연구가 필요할 것으로 생각한다. 한편, 신생아에서는 S. aureus에 의한 심각한 감염증이나 staphylococcal scalded skin syndrome 등이 발생할 수 있으며[16], E. coli에 의한 감염증이 발 생할 수도 있으므로[17], 신생아에서 S. aureus나 E. coli의 빠른 정착이 전반적인 건강에 미치는 영향에 대해서는 단정하기 어 려울 것이다.

스웨덴과 에스토니아에서 시행된 연구에서는 비아토피 군과 아토피 군의 Bifidobacterium 정착률 차이는 출생 후 1 주일째 $50 \%, 17 \%, 1$ 개월째 $69 \%, 39 \%$, 3개월째 $62 \%, 28 \%, 6$ 개월째 $42 \%, 28 \%, 12$ 개월째 $69 \%, 22 \%$ 를 보여 비아토피 군에서 $B i f-$ idobacterium 정착률이 의미있게 높았고[12], 출생후 2년째에도 $71 \%, 59 \%$ 로 차이를 보였다고 하며[18], 기존의 연구에서는 Bifidobacterium 장내 정착이 잘 일어난 군에서 아토피의 위험 이 낮은 것으로 알려져 있다. 핀란드 유아를 대상으로 한 연구 에서는 Bifidobacterium-like bacteria의 3일째 정착률은 $62 \%$ 였 고, 2개월 때 정착률은 $90 \%$ 로 증가하였다[19]. 이번 연구에서 Bifidobacterium 정착률은 비아토피 군과 아토피 군 사이에 통 계적인 유의성은 없었으며, 출생 후 9 개월까지 증가하는 양상 을 보였는데 Bifidobacterium 의 정착률은 3 일째 $13.8 \% 2$ 개월째 $31.3 \%$ 로 시간이 지날수록 증가하여 9 개월째에는 $66.7 \%$ 의 정 착률을 보였다. 외국과 우리나라 영아에서 Bifidobacterium 정 착률 차이는 이 세균에 대한 노출 정도나 식이의 차이가 작용 한 것으로 보인다. 이번 연구에서는 비아토피 군에서 3 일째 $S$. aureus, E. coli의 정착률이 높은 경향을 보였을 때에도 Bifidobacterium 의 아토피 군과 비아토피 군의 보균율은 $12.5 \%$ 와 $14.3 \%$ 로 의미 있는 차이는 관찰되지 않았다. 따라서, 우리나라 영아에서는 Bifidobacterium의 정착과정과 아토피와의 관련성 이 서구와 다를 것으로 추정된다.

이번 연구에서는 검체 채취와 운반과정에서 밀봉한 비닐 봉 투를 사용하였는데 혐기성 세균인 Bifidobacterium이 이 과정에 서 생존률이 저하되었을 가능성이 있으며, 첨가하는 항생제를 기존의 식품공전의 $40 \%$ 정도로 낮추었음에도 $\mathrm{BS}$ 선별배지에 서 일부 Bifidobacterium이 억제될 수도 있으므로 전반적인 검 출률이 낮아졌을 가능성도 있다. 또한, 이번 연구에서는 의심되 는 집락을 모두 생화학적으로 Bifidobacteria로 동정하였으므로 Bifidobacterium-like bacteria를 모두 포함한 다른 연구에 비해 검출률이 낮았을 가능성도 있으므로 단순 비교하기는 어렵다. 
Lactobacillus 의 경우 전체 영아에서 3 일째 정착률은 $10.3 \%$, 2 개월째 정착률은 $23.8 \%$ 을 보였고, 연구 기간 중 $40 \%$ 이내의 정착률을 보여 정착이 쉽지 않은 것으로 보인다. 핀란드의 한 연구에서는 Lactobacillus-like bacteria의 3일째 정착률은 $11 \%$ 2개월째 47\%를 보였는데[19], 이번 연구는 전용 배지에서 백색 의 큰 집락을 선택하여 생화학적인 동정과정을 거쳐 Lactobacillus 가 아닌 균은 배제하였으므로 기존의 연구 결과에 비해 검출률이 낮게 조사되었을 것으로 추정된다. 또한, 이 세균에 대한 노출이나 서양과 우리나라의 식이 차이도 영향을 미칠 수 있을 것으로 생각한다. 이번 연구에서 Lactobacillus 배양에 사 용한 배지는 'lactic acid bacteria'의 배양에 많이 사용하고 있는 De Man, Rogosa, Sharpe (MRS) 배지로서, sodium acetate 등의 억제제가 들어 있으나 다른 균종을 억제할 수 있는 범위가 제 한적이므로 Lactobacillus 외에도 Streptococcus, Pediococcus, Leuconostoc 등의 유산균도 자랄 수 있다[20]. 따라서, 선택적 으로 Lactobacillus를 배양하기가 어려웠다. 실제로 MRS 배지 에서 관찰된 다수의 균이 그람양성구균이었으며, Bifidobacterium이 자라는 경우도 있었다. 따라서, MRS 배지위에서 여러 종류의 'lactic acid bacteria'가 자란 경우 이 균종을 모두 동정 하기 어려우므로 새로운 동정법을 도입하거나 lactic acid bacteria로 통합하여 조사하는 방법도 고려해야 할 것으로 보인다. 이 연구에서는 장내에서 흔히 분리되며, 중요한 것으로 알려 진 4가지 균종에 대해서만 살펴보았으므로, 최근의 유전체 분 석에 의한 결과와는 다를 것으로 생각한다. 실제로 다양한 배 지에서 자란 그람양성구균이나 그람염색상 또는 생화학적으로 다른 균종의 경우 상당수는 Pediococcus, Lactococcus, Streptococcus, Eubacterium 같은 유산균으로 추정된다. 또한, E. coli 이외의 장내세균과 Bacteroides, Clostridium 등도 이번 연구에 서는 조사하지 못하였다. 장내세균총은 식이와 시기에 따라 상 당한 변화를 보일 수 있고 균수가 검출 한계 이하로 존재할 수 있으므로, 이번 연구와 같이 세균 배양을 통한 연구에서는 실 제 장내 세균총을 반영한다고 볼 수는 없다. 하지만, 이번 연구 는 기존에 쉽게 정착되거나 아토피와의 연관성이 알려진 세균 을 대상으로 아토피 발생을 추적관찰한 연구로서 배양 검사를 위주로 한 다른 연구와 비교 자료로서 의의를 가진다고 생각한 다.

자연 분만과 제왕절개 같은 분만법 차이에 따라 신생아의 세 균의 장내 정착 양상이 달라질 수 있다[1]. 핀란드의 한 연구 [21]에서는 Bifidobacterium-like bacteria의 정착률이 자연 분만 한 경우 생후 3 일째 $82.3 \%, 10$ 일째 $96.8 \%, 1$ 개월째 $90.9 \%$ 를 보 였으나, 제왕 절개의 경우 생후 3 일째 $36.7 \%, 10$ 일째 $53.6 \%, 1$ 개월째 $82.8 \%$ 를 보여 자연분만으로 태어난 신생아의 경우 대 다수가 초기 10 일 이내에 Bifidobacterium-like bacteria가 정착 하는 결과를 보였다. 분만법에 따라 장내세균총의 차이가 생기 고 아토피 위험이 다르다는 연구가 많았지만, 이번 연구에서
자연분만과 제왕절개 군에서 4가지 균종의 큰 차이는 보이지 않았다. 우리나라에서 시행된 연구에서는 아토피와 분만법의 연관성에 대해서는 이견이 있다[8,9,22].

염기서열분석 검사법의 발달로 전체 장내세균의 세균의 유 전자를 분석하여 세균총의 분포를 조사하는 방법이 최근 많이 시도되고 있다[23]. 전체 균종을 분석하기에는 한계가 있는 세 균 배양법에 비해 전체유전자염기서열 분석법은 장내 세균총 분포의 이해에 큰 도움이 될 것으로 생각한다.

이번 연구에서는 우리나라 신생아 분변에서 출생후 9개월간 E. coli, S. aureus, Bifidobacterium, Lactobacillus 등의 장내 정 착률에 대한 기초 자료를 수집하고, 이 세균들의 정착과 아토 피 발생과의 연관성을 알아보고자 하였다. 출생 후 초기 1 주일 이내에 아토피 군과 비아토피 군에서 E. coli, S. aureus 정착률 차이가 있음을 시사하였지만 통계적인 유의성은 관찰되지 않 았다. 장내 세균총은 다양한 세균으로 이루어져 있으며, 면역계 발달에 영향을 미칠 수 있으므로 출생 초기의 다양한 장내세균 의 변화와 아토피의 연관성에 대해서는 추가적인 연구가 필요 할 것으로 생각한다.

\section{ACKNOWLEDGMENTS}

이 연구는 (주)매일유업의 연구비(IRB05-01) 지원에 의해 수 행되었음.

\section{REFERENCES}

1. Johnson CL and Versalovic J. The human microbiome and its potential importance to pediatrics. Pediatrics 2012;129:950-60.

2. Qin J, Li R, Raes J, Arumugam M, Burgdorf KS, Manichanh C, et al. A human gut microbial gene catalogue established by metagenomic sequencing. Nature 2010;464:59-65.

3. Penders J, Stobberingh EE, van den Brandt PA, Thijs C. The role of the intestinal microbiota in the development of atopic disorders. Allergy 2007;62:1223-36.

4. Baker BS. The role of microorganisms in atopic dermatitis. Clin Exp Immunol 2006;144:1-9.

5. Bisgaard H, Li N, Bonnelykke K, Chawes BL, Skov T, PaludanMüller $G$, et al. Reduced diversity of the intestinal microbiota during infancy is associated with increased risk of allergic disease at school age. J Allergy Clin Immunol 2011;128:646-52.e1-5.

6. Abrahamsson TR, Jakobsson HE, Andersson AF, Björkstén B, Engstrand L, Jenmalm MC. Low diversity of the gut microbiota in infants with atopic eczema. J Allergy Clin Immunol 2012;129: 434-40, 440.e1-2.

7. Hanski I, von Hertzen L, Fyhrquist N, Koskinen K, Torppa K, Laatikainen T, et al. Environmental biodiversity, human microbiota, and allergy are interrelated. Proc Natl Acad Sci U S A 2012; 109:8334-9.

8. Park YH, Kim KW, Choi BS, Jee HM, Sohn MH, Kim KE. Relationship between mode of delivery in childbirth and prevalence of allergic diseases in Korean children. Allergy Asthma 
Immunol Res 2010;2:28-33.

9. Lee YJ, Jee HM, Kim BJ, Kim HB, Yu J, Lee SY, et al. Prevalence of allergic diseases in children according to mode of delivery. Pediatr Allergy Respir Dis 2011;21:197-206.

10. Pyun BK, Kim WK, et al. eds. Pediatric Allergy Immunology Pulmonology. 2nd ed. The Korean Academy of Pediatric Allergy and Respiratory Disease; 2013:69-72.

11. Guarner F. Hygiene, microbial diversity and immune regulation. Curr Opin Gastroenterol 2007;23:667-72.

12. Björkstén B, Sepp E, Julge K, Voor T, Mikelsaar M. Allergy development and the intestinal microflora during the first year of life. J Allergy Clin Immunol 2001;108:516-20.

13. Kalliomäki $\mathrm{M}$ and Isolauri $\mathrm{E}$. Role of intestinal flora in the development of allergy. Curr Opin Allergy Clin Immunol 2003; 3:15-20.

14. Lee HB. Effects of breastfeeding on the development of allergies. Hanyang Med Rev 2010;30:49-59.

15. Nowrouzian F, Hesselmar B, Saalman R, Strannegard IL, Aberg N, Wold AE, et al. Escherichia coli in infants' intestinal microflora: colonization rate, strain turnover, and virulence gene carriage. Pediatr Res 2003;54:8-14.

16. Yi J and Kim EC. Microbiological characteristics of methicillinresistant Staphylococcus aureus. Korean J Clin Microbiol 2010; $13: 1-6$.
17. Oh HR, Moon DS, Jang SJ, Li XM, Kim DM, Park SG, et al. Epidemiological investigation of an outbreak of Escherichia coli infections in neonatal intensive care unit of a university hospital. Korean J Clin Microbiol 2008;11:123-8.

18. Björkstén B, Naaber P, Sepp E, Mikelsaar M. The intestinal microflora in allergic Estonian and Swedish 2-year-old children. Clin Exp Allergy 1999;29:342-6.

19. Grönlund MM, Arvilommi H, Kero P, Lehtonen OP, Isolauri E. Importance of intestinal colonisation in the maturation of humoral immunity in early infancy: a prospective follow up study of healthy infants aged 0-6 months. Arch Dis Child Fetal Neonatal Ed 2000;83:F186-92.

20. Hartemink R and Rombouts FM. Comparison of media for the detection of bifidobacteria, lactobacilli and total anaerobes from faecal samples. J Microbiol Methods 1999;36:181-92.

21. Grönlund MM, Lehtonen OP, Eerola E, Kero P. Fecal microflora in healthy infants born by different methods of delivery: permanent changes in intestinal flora after cesarean delivery. J Pediatr Gastroenterol Nutr 1999;28:19-25.

22. Kim BS. Is mode of delivery associated with an increased risk for childhood asthma? Pediatr Allergy Respir Dis 2011;21:250-60.

23. Tilg $\mathrm{H}$ and Kaser A. Gut microbiome, obesity, and metabolic dysfunction. J Clin Invest 2011;121:2126-32.

$=$ 국문초록=

\title{
출생 후 9개월간 영아의 장내 세균 변화와 아토피
}

\author{
한림대학교 의과대학 ${ }^{1}$ 진단검사의학교실, ${ }^{2}$ 소아과학교실 \\ 김재석 ${ }^{1}$, 성태정 ${ }^{2}$, 박홍규 $^{2}$, 박지영 $^{1}$, 조현찬 ${ }^{1}$, 황일태 $^{2}$, 이혜란 ${ }^{2}$
}

배경: 장내 세균총은 연령, 식이, 환경에 따라 다양한 변화를 보인다. 신생아의 출생 후 장내 세균의 변화와 아토피 발생 의 연관성에 대해 여러 논란이 있다. 이 연구는 출생 후 9 개월 간 장내 세균의 변화와 아토피 발생의 연관성에 대해 알아보고자 하였다.

방법: 정상 신생아의 분변을 출생후 1일, 3 일, 7 일, 1 개월, 2 개월, 4 개월, 6 개월, 9 개월에 수집하여 Escherichia coli, Lactobacillus, Bifidobacterium, Staphylococcus aureus를 선택배지를 사용하여 배양하였다. 영아의 아토피 여부를 알기 위해 임상 소견과 함께 혈청 총 $\mathrm{IgE}$, 피부반응검사를 시행하였다.

결과: 12 개월 후 48 명의 영아에서 비아토피 군은 36 명 $(75.0 \%)$, 아토피 군은 12 명 $(25.0 \%)$ 이었다. 비아토피 군과 아토피 군이 가장 큰 차이를 보인 것은 3 일째로 E. coli 정착률 $52.4 \%, 12.5 \%$ 와 S. aureus 정착률 $38.1 \%, 0 \%$ 였으나 통계적인 차이 는 없었다 $(P=0.093, P=0.066) . E$. coli 정착률이 $50 \%$ 에 도달한 시기는 정상군에서는 3 일 이후였으나 아토피 군은 1 개월 이후였다.

결론: 영아의 아토피 군과 비아토피 군에서 장내 세균 정착률의 통계적인 차이는 관찰되지 않았다. 그러나, 비아토피 군에서는 출생 초기인 1 주일 이내에 E. coli와 S. aureus의 정착이 빠르게 일어났다. 아토피와 출생 초기의 장내세균의 정착 및 다양성과의 연관에 대해서는 추가 연구가 필요할 것으로 생각한다. [Ann Clin Microbiol 2014;17:73-79]

교신저자 : 이혜란, 431-070, 경기도 안양시 동안구 평촌동 896

한림대학교 의과대학 소아과학교실

Tel: 031-380-4110, Fax: 031-380-4107

E-mail: drran@hallym.or.kr 